\title{
STRATEGI MARKETING POLITIK CALON INDEPENDEN DALAM KONTESTASI PILKADA SERENTAK TAHUN 2017 DI KABUPATEN BUTON SELATAN
}

\author{
Ansar Suherman dan Mansur \\ Fakultas Ilmu Sosial dan Ilmu Politik Universitas Muhammadiyah Buton \\ Jl. Betoambari No. 36 Kel. Lanto Kec. Batupoaro Kota Baubau Prov. Sulawesi Tenggara, \\ e-mail: ansar.suherman@yahoo.co.id
}

\begin{abstract}
This research aims to know the marketing strategy of a political candidate from the independent online election Districts are simultaneously carried out in 2017. This research took South Buton regency location in Southeast Sulawesi Province and made of candidate La Ode Agus Mbaeda and La Ode Agus (AA) as a subject in the study because it comes from an independent or non-line political party. In identifying a political marketing strategy undertaken by the prospective spouses AA, researchers used a model of political marketing from Smith and Hirst, who use the three phases namely: segmentation, targeting, and positioning politics. The research approach applied in the research is descriptive qualitative approach. Through this approach, the problem can be a breakfast buffet clearly and details of segmentation, targeting, and Positioning Politics that will have an impact on the determination of strategies and tactics to win team consolidation. The results of this study found that the process of segmentation has been done by the team to win even though the process is not done thorough and complete. The team winning only focuses on one segment of the course, i.e. ethnic culture/social segments with the neglect of other segments which should be entered in part a process of segmentation. On the targeting of the winner, the team approach as a strategy of ethnic-based which is considered able to obtain support vote by utilizing custom personalities as the main target. It is a phenomenon in rural communities that the community would be so listen to what was said by the indigenous character. Primordialism approach in the context of rural communities in Indonesia can still be used as a decoy to get support. On the final stage, due to segmentation and targeting only focuses on one segment alone IE social culture/ethnicity, then the team winning more political positioning accentuates regional son issues because it is believed to be still strongly influences the perception community voters.
\end{abstract}

\section{Keywords: Marketing Politics, Independent Candidate, Elections}

\section{PENDAHULUAN}

Sejarah pemilihan kepala daerah secara langsung (Pilkada) di Indonesia dimulai pada tahun 2005 dan kemudian terus mengalami perubahan untuk menemukan format atau sistem pemilihan yang lebih berkualitas dan demokratis.Terlepas dari sistem dan teknis pelaksanaan Pilkada, kontestan Pilkada dituntut memiliki tingkat kedikenalan (popularitas) di tengah-tengah masyarakat sebagai wajib pilih. Popularitas adalah prasyarat mutlak yang wajib dimiliki, meskipun terkadang popularitas bukanlah faktor penentu kandidat akan memperoleh tingkat kedipilihan (elektabilitas) yang tinggi. Dalam usaha menaikkan popularitas dan citra politik dibutuhkan strategi yang efektif dan terstruktur. Tahapan-tahapan tersebut dapat dilakukan melalui proses marekting politik (segmentasi, targeting, dan positioning politik).

Segmentasi merupakan upaya untuk mengidentifikasi dan memetakan struktur serta karakteristik masyarakat. Menurut Firmanzah (2008: 157), seperti halnya dalam segmentasi pasar pada marketing komersial, dilakukan dengan menggunakan lima variabel segmentasi, yakni segmentasi geografis, demografis, psikografis, tingkah laku, dan sosial-budaya. Dalam segmentasi politik perlu memperhitungkan keberadaan dari kelompokkelompok masyarakat yang hendak dipengaruhi. Kelompok-kelompok masyarakat yang memiliki perbedaan 
dari variabel-variabel segmentasi harus diperhatikan agar usaha yang dilakukan khususnya oleh tim pemenangan politik dapat terwujud dengan efektif dan efisien. Kenyataan perbedaan karakteristik tersebut menuntut dilakukannya pendekatan yang berbeda. Dari hasil segmentasi, institusi politik atau tim pemenangan akan dapat menentukan strategi kampanye yang dapat diterapkan pada kelompok-kelompok yang berbeda tersebut.

Sedangkan positioning menurut Rise dan Trout (1981) dalam Firmanzah(2011: 218) adalah:

Keseluruhan aktifitas yang bertujuan untuk menanamkan kesan di benak pemilih agar mereka mampu membedakan produk dan jasa yang dihasilkan oleh organisasi bersangkutan. Institusiinstitusi politik harus mampu menunjukkan kekhasan produk politik dan image politiknya sehingga publik dapat memperbandingkan dengan produk dan image politik dari institusi politik lainnya.

Proses pembedaan inilah yang dilakukan dalam positioning politik, agar masyarakat dapat dengan mudah membedakan antara produk satu institusi politik dengan produk institusi politik lainnya sehingga akan menimbulkan kesan khusus yang tertanam di dalam benak setiap individu masyarakat.

Dalam kaitannya dengan kontestasi Pemilihan Kepala Daerah, positioning politik mutlak dilakukan, sebab positioning politik akan mengambil peran dalam membantu pemilih dalam membedakan antara satu kontestan dengan kontestan pesaing lainnya, terkait dengan image, produk, pesan, dan program kerja, termasuk dalam menciptakan identitas politik kontestan.

Dengan menggunakan segmentasi, targeting, dan positioning politik, institusi politik khususnya tim pemenangan akan sangat terbantu dalam menentukan strategi kampanye yang akan dilakukan. Tentu saja kegiatan kampanye yang dilakukan tidak serta merta akan langsung menimbulkan asosiasi dan harapan bagi publik, dibutuhkan proses panjang dan terstruktur dari kandidat dalam melakukan kampanye. Memiliki model kampanye yang tersusun atas perencanaan yang matang, tentunya merupakan aset yang baik dalam menonjolkan citra (image) yang mampu tertanam kuat dibenak individu pemilih.

Dalam proses suksesi kepemimpinan melalui Pilkada Serentak di Tahun 2017 mendatang, Kabupaten Buton Selatan sebagai daerah otonomi baru di Provinsi Sulawesi Tenggara, untuk pertama kalinya akan melaksanakan Pilkada. Hal ini akan memberikan tantangan baru bagi para kontestan yang ikut dalam pesta suksesi tersebut, meskipun dari seluruh kandidat yang resmi ikut adalah putera daerah jazirah Buton, dan hal yang menarik dari kontestasi tersebut adalah keikutsertaan satu pasangan calon dari jalur independen non partai politik.

Menjadi menarik disebabkan pasangan calon dari jalur independen tidak didukung oleh mesin partai politik sehingga mengharuskan mereka untuk bekerja ekstra tidak hanya dalam hal bagaimana menambah dan memaksimalkan kekuatan mesin politiknya dilapangan akan tetapi tantangan terbesarnya adalah kemampuan untuk mendapatkan dukungan finansial. Sebab biasanya, calon independen tidak begitu dilirik oleh para pemilik modal yang memiliki kepentingan dalam pembagian kue kekuasaan nantinya. Hal lain yang menarik perhatian peneliti untuk melakukan penelitian ini adalah kesamaan latar belakang sebagai putera daerah menjadi masalah tersendiri bagi tiap pasangan calon yang ikut dalam kontestasi tersebut. Sehingga peneliti tertarik untuk meneliti dan menganalisis lebih mendalam terkait kemampuan pasangan calon independen untuk mempresentasikan citra dan perbedaan dirinya dibandingkan dengan pasangan calon lainnya yang diusung dan didukung oleh partai politik agar masyarakat mampu membedakan jualan politik dari pasangan calon independen tersebut. Presentasi yang dilakukan tentu bukan sekadarnya saja, dibutuhkan sebuah metode atau strategi yang terukur dalam melakukan penonjolan citra atau image. Maka, strategi segmentasi, targeting, dan 
positioning politik yang matang dari tim pemenangan pasangan calon independen akan mampu memberikan kontribusi yang positif terutama dalam memunculkan perbedaan citra elite/tokoh dihadapan masyarakat.

\section{TUJUAN PENELITIAN}

Penelitian ini bertujuan untuk mendeskripsikan proses segmentasi, targeting, dan positioning politik yang dilakukan oleh Tim Pemenangan pasangan Calon Bupati dan Calon Wakil Bupati dari jalur independen kepada masyarakat di Kabupaten Buton Selatan.

\section{KAJIAN TEORITIK}

Beberapa penelitian terdahulu yang juga mengambil topik penelitian yang sama diantaranya adalah: 1) Penelitian oleh Pangemanan (Jurnal Politico, Vol. 1 No. 3 Tahun 2013), tentang Pemasaran Politik Pada Pemilukada di Kota Bitung Tahun 2010; dan 2) Marketing Politik Partai Gerindra Pada Pemilu Legislatif 2014 Di Kabupaten Karawang oleh Maulana Rifai (Jurnal Politikom Indonesiana Vol. 1 No.1 Tahun 2016). Dari kedua penelitian terdahulu tersebut, selain perbedaan pada subyek penelitiannya, juga berbeda dalam hal teori yang digunakan. Kedua penelitian tersebut menggunakan Konsep pemasaran atau marketing yang selama ini dikenal dengan bauran pemasaran konvensional oleh McCarthy (1960), yaitu terdiri atas komponen '4Ps' (product, price, place and promotion), sedangkan dalam penelitian ini penggunaan konsep marketing politik berfokus pada segmentasi, targetting, dan positioning politik. Perbedaan lainnya adalah, pada penelitian ini yang menjadi subyek penelitian adalah kandidat dari jalur independen sedangkan kedua penelitian tersebut masing-masing meneliti kandidat dari jalur partai politik sedangkan penelitian lainnya meneliti tentang partai politik.

Konsepsi Marketing politik ini juga memberikan kontribusi dalam menyajikan seperangkat teknik dan metode marketing dalam dunia politik. Tujuannya adalah untuk memahami, menganalisis kebutuhan dan keinginan pemilih, dan membina hubungan dengan pemilihnya. Dari hubungan tersebut, akan terbangun kepercayaan, yang pada akhirnya akan diperoleh dukungan suara pemilih. Hal yang perlu digaris bawahi, bahwa kemenangan suatu partai politik atau calon pemimpin diperoleh dengan mendapatkan suara mayoritas pemilih dalam pemilihan umum.

Kontribusi Marketing politik dalam ilmu politik terutama dalam kontestasi dan suksesi politik baik lokal maupun nasional sangat berpengaruh terhadap kerja-kerja konsolidasi yang dilakukan oleh tim pemenangan serta berpengaruh dalam usaha mendapatkan kepercayaan pemilih. Setelah melalui tahapan segmentasi, targeting, dan positioning politik, selain membantu dalam merumuskan strategi konsolidasi (konsolidasi internal dan eksternal) untuk menguatkan mesin politik dalam bekerja dan meraih dukungan pemilih sebanyak-banyaknya, yang tidak kalah pentingnya adalah mendapatkan kepercayaan dan dukungan suara pemilih.

Menurut Firmanzah (2008: 203), bahwa penggunaan metode marketing politik tidak terlepas dari tingginya persaingan dalam dunia politik sehingga dibutuhkan sebuah strategi untuk dapat memenangkan persaingan tersebut. Bahwa marketing politik adalah metode dan merupakan aplikasi dari marketing dalam konteks dunia politik, yang digunakan sebagai seperangkat instrumen oleh kontestan (individu maupun kelompok) dalam memasarkan inisiatif politik, gagasan politik, isu politik, ideologi, karakteristik pemimpin, 
dan program kerja kepada masyarakat.

Hasil akhir dari proses segmentasi, targeting, dan positioning politik adalah untuk memuluskan jalan dari para elite/tokoh politik termasuk organisasi politik untuk mendapatkan kemenangan dalam setiap kontestasi politik. Dan hal tersebut hanya dapat terwujud bila yang tertanam dibenak setiap individu masyarakat adalah mempersepsikan image yang positif mengenai individu tokoh atau organisasi politik. Prinsip pemimpin (leader) adalah bagaimana menguasai benak masyarakat seluas-luasnya. Proses-proses tersebut di atas tidak dapat dikerjakan jika tidak dilakukan proses segmentasi, targeting, dan positioning politik.

Menurut Nursal (2004: 156) dalam political marketing terdapat tiga strategi mengampanyekan political marketing, yaitu:

Pemasaran politik secara langsung kepada calon pemilih (push political marketing), pemasaran produk politik melalui media massa (pull political marketing), dan pemasaran politik melalui kelompok, organisasi atau tokoh yang berpengaruh (pass political marketing).

Segmentasi merupakan upaya untuk mengidentifikasi dan memetakan struktur serta karakteristik masyarakat. Menurut Firmanzah (2008: 156-157), seperti halnya dalam segmentasi pasar pada marketing komersial, dilakukan dengan menggunakan lima variabel segmentasi, yakni segmentasi geografis, demografis, psikografis, tingkah laku, dan sosial-budaya. Dalam segmentasi politik perlu memperhitungkan keberadaan dari kelompok-kelompok masyarakat yang hendak dipengaruhi. Kelompok-kelompok masyarakat yang memiliki perbedaan dari variabel-variabel segmentasi harus diperhatikan agar usaha yang dilakukan khususnya oleh tim pemenangan politik dapat terwujud dengan efektif dan efisien. Kenyataan perbedaan karakteristik tersebut menuntut dilakukannya pendekatan yang berbeda. Dari hasil segmentasi, institusi politik atau tim pemenangan akan dapat menentukan strategi kampanye yang dapat diterapkan pada kelompok-kelompok yang berbeda tersebut.

Setelah melakukan identifikasi terhadap peluang segmen pasar, selanjutnya adalah melakukan evaluasi terhadap beragam segmen yang ditemukan untuk kemudian memutuskan segmen mana yang menjadi target. Karena keterbatasan resources (sumber daya) dan keuangan, maka perlu menetapkan kelompok manasaja yang kemudian akan menjadi target untuk memperoleh basis dukungan suara nantinya.

Menurut Firmanzah (2011: 225) bahwa setelah dilakukan segmentasi yang berisi profil dari kelompok masyarakat, maka tahapan selajutnya adalah melakukan targeting. Pada bagian ini, perlu membuat standar dan acuan pengukuran baik berupa jumlah maupun besaran potensi pemilih. Kelompok pemilih yang memilih kuantitas yang besar haruslah menjadi target utama yang harus diolah. Selain jumlah, standar pengukuran lainnya adalah dengan melihat sejauhmana suatu kelompok dapat memberikan efek dalam menciptakan dan memengaruhi opini publik, meskipun jumlah kelompok pengaruh tersebut tidak berdasarkan pada kuantitasnya. Jadi, dapat disimpulkan bahwa dua hal yang menjadi perhatian dari kontestan politik dalam menetukan kelompok mana yang akan dijadikan target utama, yakni efek langsung dari perolahn suara dalam pemilihan, dan efek pengganda (multiplier effects). Hasil dari proses targeting inilah yang kemudian akan menjadi acuan atau tolok ukur bagi kontestan atau tim pemenangan pasangan calon dalam melakukan positioning politik.

Positioning politik dalam marketing politik adalah keseluruhan aktifitas yang bermaksud menanamkan kesan dibenak para pemilih atau konstituen agar pemilih dapat membedakan produk atau jasa yang dihasilkan dan ditawarkan oleh calon bersangkutan dengan produk atau jasa yang dihasilkan dan ditawarkan oleh pihak lainnya. Firmanzah (2011: 164) menjelaskan bahwa: 


\begin{abstract}
Dalam positioning, atribut produk dan jasa yang dihasilkan akan direkam dalam bentuk image yang terdapat dalam sistem kognitif konsumen. Dengan demikian konsumen akan dengan mudah mengidentifikasi sekaligus membedakan produk dan jasa yang dihasilkan oleh suatu perusahaan dengan mengingat image produk dan jasa bersangkutan.
\end{abstract}

Ketika konsep positioning tersebut diadopsi dalam konteks politik - dalam iklim persaingan - calon yang sedang berkontestasi harus mampu menempatkan produk politik dan image politiknya dalam benak masyarakat yang menjadi konstituen atau pemilih dalam suksesi politik tersebut. Kaitannya dalam kampanye politik, calon harus mampu menyampaikan dan menawarkan program yang berbeda dengan calon pesaing lainnya, termasuk bagaimana kemasan pesan tersebut dibuat berbeda dengan calon lainnya. Sebab jika program dan kemasan yang digunakan memiliki kesamaan dengan calon pesaing lainnya, maka pemilih akan merasakan tidak ada bedanya (indifference) yang pada akhirnya pemilih akan merasa tidak akan menghasilkan hal atau sesuatu yang berbeda. Pembedaan inilah yang dilakukan dalam positioning politik untuk menghasilkan kesan khusus dibenak pemilih.

\title{
METODE PENELITIAN
}

Pendekatan penelitian yang diterapkan dalam penelitian adalah pendekatan deskriptif kualitatif. Alasan pemilihan jenis pendekatan oleh peneliti adalah karena permasalahan dapat tergambarkan secara jelas dan terperinci mengenai Segmentasi, targeting, dan Positioning Politik yang akan berdampak pada penentuan strategi dan taktik konsolidasi organisasi dalam Pilkada Serentak pada tahun 2017 di Kabupaten Buton Selatan Provinsi Sulawesi Tenggara.Menurut Neuman (2003:146), pendekatan kualitatif merupakan penelitian yang tidak terstruktur dan bersifat menjelaskan yang didasarkan pada sampel kecil yang memberikan wawasan dan pemahaman mengenai setting masalah.

Menurut Marsh dan Stoker (2002) dalam Perdana (2012: 242):

Dalam kajian ilmu politik, metode kualitatif telah memainkan peran utama mulai dari penelitian tentang individu dan kelompok dalam kancah politik formal hingga sikap dan prilaku masyarakat diluarnya seperti perilaku para pemilih. Metode kualitatif telah banyak digunakan dalam subbidang ilmu politik - seperti komunikasi politik - yang mengharuskan para partisan dalam dunia politik mau berbicara tentang keterlibatan mereka dalam kelompok peran mereka dalam jabatan kekuasaan formal serta pandangan mereka tentang sistem politik.

Sampel dalam penelitian ini adalah pasangan calon dari jalur independen yakni Tim Pemenangan pasangan calon La Ode Agus Mbaeda dan La Ode Agus. Proses interview melibatkan dua orang dari Tim Pemenangan tersebut La Ode Endang, S.T. (Ketua Tim), dan La Ode Agus (Calon Wakil Bupati).

Menurut Punch (2005: 200), kunci pokok analisis data dalam penelitian kualitatif adalah menjawab pertanyaan how did the researcher get these conclusion from these data. Pengumpulan data dalam studi kasus dapat diambil dari berbagai sumber informasi, karena studi kasus melibatkan pengumpulan data yang "kaya" untuk membangun gambaran yang mendalam dari suatu kasus, diantaranya adalah Dokumentasi, Wawancara mendalam, dan studi pustaka Yin (1996: 51). Sedangkan analisis datanya menggunakan interactive model, teknik ini terdiri atas tiga bagian: Reduksi Data (Data Reduction), Penyajian Data (Data Display), dan Pengujian Kesimpulan (Drawing and Verifying conclusion). Sedangkan pengujian keabsahan data dilakukan dengan melakukan triangulasi untuk mendapatkan validitas dan kredibiltas data. Validitas dalam penelitian 
kualitatif mempunyai pendekatan yang berbeda dengan penelitian kuantitatif. Menurut Alawasilah, (2002: 171), validitas dalam penelitian kualitatif merujuk kepada pemahaman deskripsi, interpretasi, teori, dan generalisasi. Uji kredibilitas dilakukan dengan Triangulasi (triangulasi metode, triangulasi sumber data, dan triangulasi antar-peneliti) karena penelitian ini dilakukan oleh 2 orang peneliti, sedangkan triangulasi teori tidak dilakukan karena metode strategi marekting politik hanya menggunakan teori Smith dan Hirst.

\section{HASIL PENELITIAN DAN PEMBAHASAN}

Strategi Marketing Politik

Mengutip pernyataan O’Shaugnessy (2001) dalam Firmanzah, (2011: 197), bahwa strategi marketing politik bukanlah jaminan untuk mendapatkan kemenangan, akan tetapi sebatas menyediakan tools yang berfungsi menjaga relasi dengan pemilih agar kepercayaan masyarakat pemilih dapat terbangun yang pada akhirnya kepercayaan dan dukungan suara akan diberikan oleh mereka.

Hal terpenting dalam setiap kompetisi politik adalah bagaimana merebut hati para pemilih agar pemilih mau memberikan suaranya. Untuk mendapatkan dukungan tersebut dibutuhkan strategi marketing politik yang mampu menyampaikan pesan politiknya kepada pemilih. Ada tiga langkah yang harus digunakan oleh kandidat agar dapat secara maksimal dapat menyampaikan pesan-pesan komunikasinya kepada pemilih, dan mendapatkan basis dukungan yang jelas, yaitu: segmentasi, targeting, dan positioning.

Merujuk kepada penjelasan tentang konsep dan teori tentang marketing politik, peneliti akan mencoba mendeskripsikan hasil wawancara dengan informan yang merupakan tim pemenangan pasangan calon AA tentang strategi marketing politiknya pada Pilkada Buton Selatan tahun 2017 mendatang. Meskipun dalam wawancara tersebut informan tidak secara langsung menjelaskan langkah-langkah strategi marketing politik yang dilakukan oleh Tim Pemenangan Pasangan calon AA, namun peneliti akan mendeskripsikan hasil penelitian tersebut berdasarkan pada penjelasan di bagian Kajian Pustaka sebelumnya.

Segmentasi Pasangan Calon AA

Segmentasi perlu dilakukan dalam rangka untuk melakukan identifikasi dan klasifikasi karakteristik beberapa kelompok masyarakat agar penerapan strategi dan taktik tim pemenangan dapat berjalan efektif dan efisien.

Menurut Endang (Ketua Tim Pemenangan), bahwa langkah-langkah yang dilakukan oleh Tim Pemenangan Pasangan AA, adalah dengan melakukan pemilahan wilayah beradasarkan etnis suku terbesar dalam suatu wilayah. Dikarenakan pasangan AA merupakan pasangan yang berasal dari salah satu etnis terbesar di Kabupaten Buton Selatan yakni etnis Cia-Cia, maka penetapan fokus kerja pengorganisiran dilakukan pada wilayah yang dihuni oleh etnis tersebut. Menurutnya, karena kesamaan latar belakang sosialbudaya, maka diasumsikan akan lebih mudah melakukan pendekatan sosio-kultural untuk mendapatkan dukungan dari masyarakat setempat.Selain mengorganisir pada pada wilayah yang dihuni oleh etnis Cia-Cia, tim juga melakukan pengorganisiran pada basis-basis anak muda di pedesaan. Dengan membawa slogan "Majuko Anak Muda", tim berharap dapat menjadi stimulus bagi anak muda untuk ikut bergabung dalam barisan tim pemenangan pasangan AA.

Slogan "siap disumpah secara adat jika terpilih untuk tidak melakukan korupsi” diyakini oleh tim pemenangan dapat secara ampuh memengaruhi pikiran para tetua adat. Sebab, sampai saat ini belum ada satupun pasangan calon yang bersedia untuk melakukan hal semacam itu. Sehingga slogan tersebut terus digencarkan dengan target dan sasaran para tokoh-tokoh adat atau para orang tua. 
Menurut peneliti, apa yang dilakukan oleh tim pemenangan Pasangan AA merupakan bagian dari segementasi dalam marketing politik. Meskipun tim pemenangan tidak secara lengkap dan mendetail melakukan proses tahapan segmentasi, yakni yakni segmentasi geografis, demografis, psikografis, tingkah laku, dan sosial-budaya. Dalam hal ini, tim pemenangan berusaha melakukan pemetaan untuk mengidentifikasi daerah-daerah manasaja yang akan menjadi fokus membesarkan dukungan dengan berbasis etnis atau pendekatan sosial-budaya, dan mengklasifikasi kelas anak muda sebagai bagian yang potensial untuk dapat diajak bergabung dalam pemenangan pasangan tersebut, serta mencoba mengambil sentimen positif para tokoh adat dengan mengangkat isu berani untuk disumpah secara adat untuk tidak melakukan korupsi ketiak terpilih menjadi bupati dan wakil bupati Buton Selatan.

\section{Targeting Politik Pasangan Calon AA}

Pasangan calon AA umumnya menitikberatkan pada penggunaan slogan-slogan putra daerah yang apaham akan budaya dan nilai-nilai kearifan lokal sehingga yang menjadi targetnya adalah para orang tua dan tokoh-tokoh adat.

Menurut peneliti, penentuan orang tua dan para tokoh adat sebagai target utama dalam kerja-kerja membesarkan basis dukungan suara oleh tim pemenangan pasangan AA adalah dikarenakan adanya fenomena di masyarakat pedesaan bahwa masyarakat akan sangat mendengarkan apa yang dikatakan oleh para tokoh adat. Pendekatan primordialisme oleh pasangan calon AA dalam konteks masyarakat Indonesia memang masih dapat dijadikan sebagai pemikat untuk mendapatkan dukungan masyarakat pemilih. Dengan ikatan kedaerahan dan ikatan etnis yang sama atau yang biasa diistilahkan dengan putra daerah, banyak masyarakat yang kemudian menjatuhkan pilihannya kepada sesama etnisnya tanpa mempertimbangkan kapasitas calon sesama etnisnya tersebut yang kemudian mengabaikan kapasitas calon yang berbeda etnis. Irasionalitas pemilih dengan ikatan primordial ini banyak terjadi di Indonesia dan hal tersebut merupakan ancaman dalam pembangunan demokrasi yang lebih maju dan berkualitas di negeri ini. Pada bagian ini, (Firmanzah, 2011: 244) menyatakan bahwa perasaan suka tidak suka merupakan pertimbangan dari pemilih tradisional dan hal tersebut mengidikasikan adanya pertimbangan afektif dari pemilih tradisional tersebut.

\section{Positioning Politik Pasangan Calon AA}

Positioning politik dalam marketing politik adalah keseluruhan aktifitas yang bermaksud menanamkan kesan dibenak para pemilih atau konstituen agar pemilih dapat membedakan produk atau jasa yang dihasilkan dan ditawarkan oleh calon bersangkutan dengan produk atau jasa yang dihasilkan dan ditawarkan oleh pihak lainnya. Firmanzah (2011: 164) menjelaskan bahwa dalam positioning, atribut produk dan jasa yang dihasilkan akan direkam dalam bentuk image yang terdapat dalam sistem kognitif konsumen. Dengan demikian konsumen akan dengan mudah mengidentifikasi sekaligus membedakan produk dan jasa yang dihasilkan oleh suatu perusahaan dengan mengingat image produk dan jasa bersangkutan.

Hal yang coba ditanamkan dibenak pemilih oleh tim pemenangan pasangan calon AA sebagai pembeda dari pasangan calon lainnya yang ikut berkompetisi dalam Pilkada Kabupaten Buton Selatan sesuai dengan apa yang disampaikan langsung oleh La Ode Agus (Calon Wakil Bupati) adalah pendekatan budaya, program anti korupsi, dan semangat anak muda.

Menurut peneliti, ketiga isu tersebut terus dikampanyekan oleh tim pemenangan dalam setiap kegiatan kampanye dan sosialisasi di tengah-tengah masyarakat. Meskipun pada kenyataannya, keberadaan isu-isu tersebut saat ini belumlah menjadi kebutuhan mendasar bagi masyarakat di Kabupaten Buton Selatan terlebih daerah ini adalah daerah otonomi baru yang masih sangat membutuhkan program-program pembangunan yang 
lebih konkret, diantaranya: pembangunan jalan desa, sekolah-sekolah, sarana peribadatan, dan lain-lain.

Pendekatan budaya atau pendekatan kedaerah yang dilakukan oleh Pasangan Calon AA melalui penguatan pada satu etnis tertentu menurut peneliti merupakan langkah praktis namun juga pragmatis. Dikatakan praktis disebabkan, seperti yang telah peneliti jelaskan pada bagian pembahasan tentang targeting di atas, bahwa keuntungan dari pendekatan terhadap basis pemilih tradisional adalah pertimbangan afektif pemilih tradisional yang hanya melihat latar belakang kesamaan suku atau etnis, dan mengabaikan hal yang paling mendasar bagi seorang calon pemimpin yaitu kapasitas dan kapabilitasnya. Sedangkan bagian pragmatisnya adalah tim pemenangan pasangan calon AA tidak dapat menunjukkan analisis atau kajian ilmiahnya tentang kecenderungan dukungan masyarakat etnis Cia-Cia dalam Pilkada Buton Selatan. Hal lain yang tidak dipikirkan oleh Tim Pemnenangan Pasangan Calon AA adalah adanya kecenderungan kemajuan kualitas kesadaran politik masyarakat di Kabupaten Buton Selatan yang sudah banyak memiliki preferensi dan referensi politik, sehingga menurut hemat peneliti, sentimen etnis sudah tidak begitu ampuh memengaruhi pemilih. Ditambah lagi, masih ada pasangan calon lainnya yang juga ikut dalam kontestasi Pilkada Buton Selatan yang beretnis sama dengan pasangan calon AA. Sehingga peneliti menyatakan bahwa jika program dan kemasan yang digunakan memiliki kesamaan dengan calon pesaing lainnya, maka pemilih akan merasakan tidak ada bedanya (indifference) yang pada akhirnya pemilih akan merasa tidak akan menghasilkan hal atau sesuatu yang berbeda.

Terkait dengan penggunaan isu anti korupsi dalam kampanye dan ssialisasi pasangan calon AA, menurut peneliti tidak akan begitu memberikan dampak kepada perolehan dukungan pemilih, dikarenakan masyarakat di daerah tersebut belum memiliki pengalaman terhadap pejabat yang melakukan korupsi, meskipun sebelumnya telah terjadi penangkapan Sekretaris Daerah Kabupaten Buton Selatan namun kasus korupsinya bukan dilakukan di Pemerintahan Kabupaten Buton Selatan melainkan di Pemerintahan Kota Baubau - Sekretaris daearah Kabupaten Buton Selatan dulunya adalah PNS di Kota Baubau.

Hal penting yang kemudian menjadi catatan peneliti adalah penggunaan media dalam penyampaian pesan komunikasi kepada masyarakat pemilih. Sejak dimulainya tahapan kampanye oleh Komisi Pemilihan Umum Daerah (KPUD) Buton Selatan di Bulan Nopember, pasangan ini belum pernah sekalipun melakukan kampanye terbuka di lapangan dengan mobilisasi massa. Berdasarkan wawancara dengan ketua Tim Pemenangan, mengatakan bahwa metode yang digunakan adalah metode door-to-door. Dalam metode ini, tim menyebarkan selebaran, stiker, dan pamflet yang berisi program andalan dari pasangan calon AA. Menurutnya, bahwa langkah tersebut dirasa cukup efektif dalam menyampaikan program-program kerja pasangan calon AA kepada masyarakat.

\section{PENUTUP}

\section{Kesimpulan}

Beberapa kesimpulan yang dapat diambil oleh adalah sebagai berikut:

1. Proses segmentasi telah dilakukan oleh tim pemenangan pasangan calon AA meskipun proses segmentasi tersebut tidaklah dilakukan secara menyeluruh dan lengkap, yakni segmentasi geografis, demografis, psikografis, tingkah laku, dan sosial-budaya. Tim pemenangan hanya menitik beratkan pada satu segmen saja yakni segmen etnis/sosial budaya dengan mengabaikan segmen lainnya yang seharusnya masuk dalam bagian proses segmentasi. Dari proses segmentasi yang dilakukan terlihat bahwa apa yang dilakukan oleh tim pemenangan Pasangan AA merupakan salah satu bagian dari 
segmentasi dalam marketing politik. Dalam hal ini, tim pemenangan berusaha melakukan pemetaan untuk mengidentifikasi daerah-daerah manasaja yang akan menjadi fokus membesarkan dukungan dengan berbasis etnis atau pendekatan sosial-budaya, dan mengklasifikasi kelas anak muda sebagai bagian yang potensial untuk dapat diajak bergabung dalam pemenangan pasangan tersebut, serta mencoba mengambil sentimen para tokoh adat dan atau orang tua dengan mengangkat isu berani untuk disumpah secara adat untuk tidak melakukan korupsi ketiak terpilih menjadi bupati dan wakil bupati Buton Selatan.

2. Sebagai kelanjutan dari proses segmentasi, pada bagian targeting, tim pemenangan kemudian menjadikan pendekatan berbasis etnis sebagai strategi yang dianggap dapat memperoleh dukungan suara pemilih dengan memanfaatkan para orang tua atau para tokoh adat sebagai target utama dalam kerjakerja membesarkan basis dukungan suara oleh tim pemenangan pasangan AA. Hal tersebut merupakan fenomena di masyarakat pedesaan bahwa masyarakat akan sangat mendengarkan apa yang dikatakan oleh para tokoh adat. Pendekatan primordialisme oleh pasangan calon AA dalam konteks masyarakat Indonesia memang masih dapat dijadikan sebagai pemikat untuk mendapatkan dukungan masyarakat pemilih. Dengan ikatan kedaerahan dan ikatan etnis yang sama atau yang biasa diistilahkan dengan putra daerah, banyak masyarakat yang kemudian menjatuhkan pilihannya kepada sesama etnisnya tanpa mempertimbangkan kapasitas calon sesama etnisnya tersebut yang kemudian mengabaikan kapasitas calon yang berbeda etnis. Irasionalitas pemilih dengan ikatan primordial ini banyak terjadi di Indonesia dan hal tersebut merupakan ancaman dalam pembangunan demokrasi yang lebih maju dan berkualitas di negeri ini.

3. Dikarenakan pada proses segmentasi dan targeting hanya menitikberatkan pada satu segmen tertentu saja yakni segmentasi sosial budaya/etnis, maka dalam proses positioning politik dapat disimpulkan bahwa tim pemenangan akan mudah dalam membetuk citra pasangan calon AA dikarenakan isi pesannya hanya terfokus pada salah satu isu yakni isu putra daerah. Meskipun hal yang coba ditanamkan dibenak pemilih termasuk program anti korupsi, dan membawa isu anak muda akan tetapi isu putra daerah lebih ditonjolkan karena isu putra daerah diyakini masih merupakan isu yang masih kuat memengaruhi persepsi masyarakat pemilih, sebab masyarakat pemilih di pedesaan yang oleh peneliti dikategorikan sebagai pemilih tradisional masih mengedepankan pilihan primordialisme dan mengabaikan pilihan rasional. Kondisi ini dapat menjadi potensi dan peluang bagi pasangan calon AA untuk meraup dukungan yang besar dari salah satu etnis terbesar di Kabupaten Buton Selatan karena memiliki latar belakang etnis atau suku yang sama.

\section{Saran}

1. Sebagai calon independen yang tentu saja memiliki keterbatasan mesin politik dibandingkan dengan calon yang diusung oleh partai politik, maka proses segmentasi perlu dilakukan secara lengkap dikarenakan proses segmentasi politik bertujuan dalam mengkalkulasi keberadaan dari kelompokkelompok masyarakat yang hendak dipengaruhi. Kelompok-kelompok masyarakat yang memiliki perbedaan dari variabel-variabel segmentasi harus diperhatikan agar usaha yang dilakukan khususnya oleh tim pemenangan politik dapat terwujud dengan efektif dan efisien.

2. Dalam rangka memberikan pembelajaran politik yang berkualitas dan mendorong kemajuan kehidupan berdemokrasi di Indonesia, maka sentimen kedaerahan/priomodialisme seharusnya tidak menjadi pilihan 
utama dalam melakukan targetisasi potensi pemilih. Telah terbukti bahwa sentimen-sentimen etnis hanya akan semakin menguatkan ancaman disintegrasi bangsa dan semakin menyuburkan benih-benih konflik sosial.

3. Perlunya menanamkan brand image dalam proses positioning politik sebagai diferensiasi dari kontestan lainnya adalah sebuah keharusan agar masyarakat pemilih dapat dengan mudah mengidentifikasi dan membedakan calon yang satu dengan yang lainnya, akan tetapi diferensiasi tersebut tidaklah harus dengan menonjolkan salah satu isu yang dapat menjadi benih-benih disintegrasi dan konflik di tingkat lokal. Selain itu, mengangkat isu putra daerah secara pragmatis dapat menciptakan irasionalitas pemilih dalam mempertimbangkan kualitas personal calon pemimpinnya.

\section{DAFTAR PUSTAKA}

\section{Buku dan Tesis}

Alawasilah, Chaedar. (2002). "Pokoknya Kualitatif: Dasar-Dasar Rancangan dan Melakukan Penelitian Kualitatif'. Jakarta: Pustaka Raya.

Firmanzah, (2008). “Marketing Politik: Antara Pemahaman dan Realitas”. Jakarta: Yayasan Obor Indonesia.

Firmanzah, (2011) "Mengelola Partai Politik: Komunikasi dan Positioning Ideologi Politik di Era Demokrasi”. Jakarta: Yayasan Obor Indonesia

Marsh, David. \& Gerry Stroker (2002). "Teori dan Metode dalam Ilmu Politik”. Dalam Perdana, Inco Hary. (ed.). Tesis: Political Marketing Partai Politik Baru Menuju Pemilu 2014. Studi Kasus: Strategi Pemenangan Partai NasDem. Jakarta: Universitas Indonesia.

Neuman, W. Lawrence. (2003). "Social Research Methods: Qualitative and Quantitative Approaches (fifth Ed)”. Boston: Allyn and Bacon., Dan.

Nursal, Adman., (2004). "Political marketing: Strategi memenangkan Pemilu”. Jakarta: Gramedia Pustaka Utama

O’Shaugnessy, N. (2001). "The Marketing of Political Marketing”. European Journal of Marketing. Dalam Firmanzah (ed.) "Mengelola Partai Politik: Komunikasi dan Positioning Ideologi Politik di Era Demokrasi”. Jakarta: Yayasan Obor Indonesia: hal. 197.

Punch, Keith F. (2005). "Introduction to Social Research: Quantitative and Qualitative Approach". London: Sage Publications.

Ries, A. \& Trout, J. (1981). "Positioning, The Battle of Your Mind”. Dalam Firmanzah (ed.), "Mengelola Partai Politik: Komunikasi dan Positioning Ideologi Politik di Era Demokrasi”. Jakarta: Yayasan Obor Indonesia: hal. 218. 


\section{Jurnal Ilmu Sosial Vol. 16 | No. 1 | Februari 2017 | Hal. 9-19}

Yin, Robert K. (1996). “Case Study Research Design and Methods”. Washington: COSMOS Corporation.

Jurnal

Perdana, Inco Hary. (2012).“Political Marketing Partai Politik Baru Menuju Pemilu 2014. Studi Kasus: Strategi Pemenangan Partai NasDem". Tesis: Universitas Indonesia. 